Proceedings

\title{
Assessment of Phytochemicals and Antioxidant Properties of Root Extracts of Rubia cordifolia L. in Different Solvent Systems
}

\author{
Swapnil C. Kamble 1,*, Ravikiran Humbare ${ }^{1}$, Joyita Sarkar ${ }^{2}$ and Anjali A. Kulkarni ${ }^{3}$ \\ 1 Department of Technology, Savitribai Phule Pune University, Ganeshkhind, Pune, Maharashtra 411 007, \\ India \\ 2 Institute of Chemical Technology Mumbai, Marathwada Campus, Jalna, BT-6/7, Biotechnology Park, \\ Additional MIDC Area, Aurangabad Road, Jalna, Maharashtra 43120, India; \\ j.sarkar@marj.ictmumbai.edu.in \\ 3 Department of Botany, Savitribai Phule Pune University, Ganeshkhind, Pune, Maharashtra 411 007, India \\ * Correspondence: sckamble@unipune.ac.in; Tel.: +91-9404726353 \\ † The 1st International Electronic Conference on Plant Science, 1-15 December 2020. \\ Published: 30 November 2020
}

\begin{abstract}
Rubia cordifolia L. is an important plant used in Ayurvedic and Siddha medicinal systems of India for treatment of blood disorders. Of all the plant parts, roots of R. cordifolia are the most suitable source of effective secondary metabolites. The present work investigated phytochemical content and antioxidant potential of $R$. cordifolia root powder extracted in different solvents. Total polyphenols and flavonoids content were estimated. High antioxidant activity was corroborated with DPPH, hydrogen peroxide, nitric oxide, reducing power and total antioxidant assays. Obtained results showed that ethanol extracts were most potent over methanol, aqueous and PBS extracts for DPPH, hydrogen peroxide and reducing power assays. In contrast, methanol and aqueous extracts had higher potency in nitric oxide and total antioxidant assays. Encouraging results were obtained for antioxidant activity even upon PVPP treatment that removed the polyphenols from the extracts. The results suggest a potential of ethanol/methanol extracts for anti-cancer cellular activities as many reports earlier have shown that antioxidant activities are closely correlated with anticancer activities.
\end{abstract}

Keywords: root extract; Rubia cordifolia L.; secondary metabolites; multiple solvents

\section{Introduction}

Rubia cordifolia L. belongs to the family Rubiaceae and is largely distributed from Africa to tropical Asia, China, Japan and Australia. The active compounds of $R$. cordifolia are 1-hydroxy,2methoxy anthraquinone,3-dimethoxy 2 carboxy anthraquinone, rubiadin, mangistin, alizarin, garancin, rubiprasin A,B,C, ruiearbonls, mollugin and furomollugin [1]. The roots of $R$. cordifolia are used for the preparation of aqueous, ethanol, methanol, chloroform and dichloromethane extracts. Their therapeutic activities with special reference to anticancer properties are listed in Table 1. 
Table 1. Anticancer potential/ activities of R. cordifolia.

\begin{tabular}{|c|c|c|c|}
\hline Solvent & Plant Part & Cell Line/Animal Model & Reference \\
\hline Ethanol & Root & Anti-cancer activity in HeLa and HepG-2 cells & [2] \\
\hline Ethanol & Root & $\begin{array}{l}\text { Anti-thrombotic and anti-angiogenic effects in zebra } \\
\text { fish }\end{array}$ & [3] \\
\hline Ethanol & Root & $\begin{array}{l}\text { Antioxidant activity which prevents the ethanol- } \\
\text { induced immunosuppression in rats }\end{array}$ & [4] \\
\hline Methanol & Root & Cardio protective effect in Wister rat & [5] \\
\hline Methanol & Root & $\begin{array}{l}\text { Improves the effect against DEN induced } \\
\text { hepatocellular carcinoma }\end{array}$ & [6] \\
\hline Methanol & Root & $\begin{array}{l}\text { Anti-proliferative activity on human colon cancer } \\
\text { cells }\end{array}$ & [7] \\
\hline Methanol & Root & $\begin{array}{l}\text { Anticancer and anti-inflammatory activities in } \\
\text { carrageenan-induced rat-paw oedema model }\end{array}$ & [8] \\
\hline Aqueous & Aerial & $\begin{array}{l}\text { Anti-diarrheal and anti-inflammatory activities in } \\
\text { male Swiss albino mice }\end{array}$ & [9] \\
\hline Aqueous & $\begin{array}{l}\text { Whole } \\
\text { plant }\end{array}$ & $\begin{array}{l}\text { Inhibits the multiplication of rotavirus by promoting } \\
\text { virus induced apoptosis in rhesus monkey kidney } \\
\text { cell line MA-104 cells }\end{array}$ & [10] \\
\hline Chloroform & $\begin{array}{l}\text { Whole } \\
\text { plant }\end{array}$ & $\begin{array}{l}\text { Anti-tumor activity on tumor models such as ascites } \\
\text { leukaemia, lung cancer, melanoma and sarcoma cell } \\
\text { lines }\end{array}$ & [11] \\
\hline Dichloromethane & Root & $\begin{array}{c}\text { Inhibition in human leukemia cells and human } \\
\text { histolytic lymphoma cell line }\end{array}$ & [12] \\
\hline $\begin{array}{c}\text { Cyclic } \\
\text { hexapeptides }\end{array}$ & $\begin{array}{l}\text { Whole } \\
\text { plant }\end{array}$ & Anti-tumor activity & [13] \\
\hline
\end{tabular}

Different extracts have shown varied potential and a comparative account among the extracts is missing. We hereby determined anti-oxidant activities of these extracts. We identified methanol extract of the root as the most suitable solvent for anti-oxidant activities.

\section{Experiments}

\subsection{Plant Collection}

Powder forms of R. cordifolia (root) was collected from Maharashtra Arogya Mandal, Hadapsar Pune, Maharashtra, India. The powdered forms of plant was selected due to established reports of maximal antioxidant and anti-cancer activity [2]. They were stored in air tight containers for future use.

\subsection{Preparation of Extracts}

Extracts of powders were prepared in ethanol (64-17-5, HiMedia, Mumbai, India), methanol (6756-1, HiMedia, Mumbai, India) or distilled water as described previously [14]. In brief, powder of $R$. cordifolia were extracted with solvent (ethanol, methanol or aqueous) by conventional Soxhlet apparatus (4951, Goel Scientific, Pune, India) extraction under the temperature of $60^{\circ} \mathrm{C}$. After the exhaustive extraction, the extract was evaporated to dryness by rotary evaporator (Aditya scientific, Hyderabad, India) and if it was not dried then under reduced pressure and controlled temperature the extract was further concentrated using concentrator (5305000304, Eppendorf, Pune, India) and stored at room temperature for future use. PBS (Phosphate Buffer Saline) extracts of $R$. cordifolia was made by mixing the powder of the root in media $(50 \mathrm{mg} / \mathrm{mL})$. The mixture was incubated for different time intervals $(0,5,10,15,20,25$ and $30 \mathrm{~min})$ in water bath at $37^{\circ} \mathrm{C}$ before evaluation. 


\subsection{Phytochemical Screening}

The presence of secondary metabolites viz. alkaloids, saponins, tannins, phenols, glycosides, terpenes, carotenoids and quinones was detected using the standard tests [15].

\subsection{Optimization of PVPP for the Removal of Polyphenols from Plant Extracts}

The plant extracts were treated with 10\% Polyvinylpolypyrrolidone (PVPP) (9003-39-8, HiMedia, Mumbai, India) made in respective solvents for the removal of polyphenols. The extracts $(5 \mathrm{~mL})$ were treated with PVPP $(5 \mathrm{~mL})$ in respective solvents and kept on a shaking incubator (238019, Thermo Fisher, Pune, India) at $37^{\circ} \mathrm{C}$ overnight. The supernatant will have extract with no phenols, as the polyphenols bind with PVPP and settle at the bottom. The supernatant which contains the pure extract was used for further experiments [16].

\subsection{Quantification of Phenols}

Phenolic content was determined according to the method given earlier [17]. $1 \mathrm{~mL}$ of $1 \mathrm{mg} / \mathrm{mL}$ extract and gallic acid (5995-86-8, HiMedia, Mumbai, India) with the concentration of 20, 40, 60, 80 and $100 \mu \mathrm{g} / \mathrm{mL}$ was mixed with $0.5 \mathrm{~mL}$ of $1 \mathrm{~N}$ Folin- Ciocalteu reagent. Mixture was kept for $5 \mathrm{~min}$, followed by addition of $1 \mathrm{~mL}$ of $20 \%$ sodium carbonate (497-19-8, HiMedia, Mumbai, India). After 10 min incubation at room temperature, absorbance was measured at $730 \mathrm{~nm}$ using UV- Vis spectrophotometer (UV-1800, Shimadzu analyticals, Mumbai, India). Gallic acid was used as the standard.

\subsection{Quantification of Flavonoids}

Flavonoid content in the extract was determined according to the method given earlier [18]. 1 $\mathrm{mL}$ of extract and quercetin (6151-25-3, HiMedia, Mumbai, India) with the concentration of 100, 200, 300,400 and $500 \mu \mathrm{g} / \mathrm{mL}$ was mixed with $1.25 \mathrm{~mL}$ of distilled water and $75 \mu \mathrm{L}$ of $5 \%$ of sodium nitrite (7632-00-0, HiMedia, Mumbai, India) solution incubated for $5 \mathrm{~min}, 150 \mu \mathrm{L}$ of $10 \%$ aluminium chloride (7446-70-0, Sigma-Aldrich, Pune, India) solution was added. After incubation of $6 \mathrm{~min}, 500 \mu \mathrm{L}$ of $1 \mathrm{M}$ sodium hydroxide (1310-73-2, HiMedia, Mumbai, India) and $275 \mu \mathrm{L}$ of distilled water were added to prepare the mixture. The absorbance was read at $510 \mathrm{~nm}$ using UV- Vis spectrophotometer (UV-1800, Shimadzu Analyticals, Mumbai, India). Quercetin was used as the standard.

\subsection{Antioxidant Assays}

\subsubsection{DPPH Assay}

DPPH (2,2-diphenyl-1-picrylhydrazyl) scavenging activity was measured with spectrophotometer method described previously [19]. To the $0.5 \mathrm{~mL}$ extract solution with and without PVPP, made in respective solvents of concentration ranging from 20-100 $\mu \mathrm{g}, 1 \mathrm{~mL}$ of $0.2 \mathrm{mM}$ DPPH (1898-66-4, HiMedia, Mumbai, India) made in ethanol was added and volume was made up to $2 \mathrm{~mL}$ with methanol, and incubated for $30 \mathrm{~min}$ at room temperature. The absorbance was measured at $517 \mathrm{~nm}$ against blank. The percentage of inhibition of DPPH was calculated as follows: Ascorbic acid (50-81-7, HiMedia, Mumbai, India) was used as the standard and the scavenging effect on DPPH was expressed in terms of ascorbic acid equivalents.

$$
\text { Percent scavenging }=\frac{((\text { Acontrol }- \text { Asample }) \times 100)}{\text { Acontrol }},
$$

\subsubsection{Hydrogen Peroxide Assay}

The scavenging effect of hydrogen peroxide was determined as per [20]. $1 \mathrm{~mL}$ of extract solution treated with and without PVPP, of concentration ranging from $20-100 \mu \mathrm{g}$ was treated with $0.6 \mathrm{~mL}$, $40 \mathrm{mM}$ of hydrogen peroxide (7722-84-17732-18-5, Thermo Fisher, Pune, India) prepared in phosphate buffer ( $\mathrm{pH} \mathrm{7.4)}$ ) for $10 \mathrm{~min}$. The absorbance was read at $230 \mathrm{~nm}$ against blank which 
contains only $\mathrm{H}_{2} \mathrm{O}_{2}$. Ascorbic acid was used as standard and the scavenging effect of hydrogen peroxide was expressed in terms of ascorbic acid equivalents.

$$
\text { Percent scavenging }=\frac{((\text { Acontrol }- \text { Asample }) \times 100)}{\text { Acontrol }},
$$

\subsubsection{Scavenging Activity of Nitric Oxide}

Nitric oxide was generated from sodium nitroprusside and its scavenging effect was determined as per [21]. Different concentration from 20-100 $\mu \mathrm{g}$ of $1 \mathrm{~mL}$ of extract solution with and without PVPP, phosphate buffer $1 \mathrm{~mL}$ ( $\mathrm{pH} 7.4$ ) was used to prepare sodium nitroprusside (13755-38-9, HiMedia, Mumbai, India) $0.5 \mathrm{~mL}, 10 \mathrm{mM}$, and then incubated for $5 \mathrm{hrs}$ at $25{ }^{\circ} \mathrm{C}$. After $5 \mathrm{hrs}$ of incubation, $0.5 \mathrm{~mL}$ of supernatant liquid was removed and $0.5 \mathrm{~mL}$ of Griess reagent (G7921, Thermo Fisher, Pune, India) $(1 \mathrm{mM})$ prepared in distilled water was added. The absorbance of the chromophore formed during diazotization of nitric oxide with sulphanilamide and its subsequent coupling with $\mathrm{N}$-(1-naphthyl) ethylene-diamine and absorbance was read at $546 \mathrm{~nm}$. Ascorbic acid was used as standard and the nitric oxide scavenging was expressed in terms of ascorbic acid equivalents.

$$
\text { Percent scavenging }=\frac{((\text { Acontrol }- \text { Asample }) \times 100)}{\text { Acontrol }}
$$

\subsubsection{Total Antioxidant Capacity}

The total antioxidant capacity was determined by phosphomolybdate assay [22]. $1 \mathrm{~mL}$ of extract with and without PVPP, of concentration prepared in respective solvents, ranging from 20-100 $\mu \mathrm{g}$ was taken in centrifuge tube and $1 \mathrm{~mL}$ of reagent containing $0.6 \mathrm{M}$ sulphuric acid (7664-93-9, HiMedia, Mumbai, India), 28 mM sodium phosphate (10049-21-5, Thermo Fisher, Pune, India) and 4 $\mathrm{mM}$ ammonium molybdate (12054-85-2, Thermo Fisher, Pune, India) was added. The tubes were incubated at $95^{\circ} \mathrm{C}$ for $90 \mathrm{~min}$, and were cooled to room temperature, and absorbance was read at 695 $\mathrm{nm}$. Ascorbic acid was used as standard and the total antioxidant capacity was expressed in terms of ascorbic acid equivalents.

$$
\text { Percent scavenging }=\frac{((\text { Acontrol }- \text { Asample }) \times 100)}{\text { Acontrol }}
$$

\subsubsection{Assay of Reducing Power}

The reducing power assay was determined by Spectrophotometric method of Oyaizu (1986) [23]. The extract solution with and without PVPP, $2.5 \mathrm{~mL}$ made in respective solvents, of various concentrations ranging from $20-100 \mu \mathrm{g}$ was treated with $2.5 \mathrm{~mL}$ of $0.2 \mathrm{M}$ phosphate buffer ( $\mathrm{pH}$ 6.6), $2.5 \mathrm{~mL}$ of $1 \%$ potassium ferricyanide (13746-66-2, Thermo Fisher, Pune, India), incubated at $50{ }^{\circ} \mathrm{C}$ for $20 \mathrm{~min}$, cooled, $2.5 \mathrm{~mL}$ of $10 \%$ trichloro acetic acid (76-03-9, HiMedia, Mumbai, India) was added and centrifuged at $3000 \mathrm{rpm}$ for $10 \mathrm{~min}$. The upper layer $(2.5 \mathrm{~mL})$ of the solution was removed and 2.5 $\mathrm{mL}$ of methanol and $0.5 \mathrm{~mL}$ of $0.1 \%$ ferric chloride (10025-77-1, HiMedia, Mumbai, India) solutions were added, the absorbance of the resulting solution was read at $700 \mathrm{~nm}$. Ascorbic acid was used as standard and the reducing power was expressed in terms of ascorbic acid equivalents.

$$
\text { Percent scavenging }=\frac{((\text { Acontrol }- \text { Asample }) \times 100)}{\text { Acontrol }}
$$

\subsection{Statistical Analysis}

All experiments were performed in triplicate. All the values were expressed as mean \pm standard error of mean. The data was analysed by Student-Newman-Keuls test using Sigma Plot version 14 
(Systat software Inc., San Jose, CA, USA) and IC50 values calculated using Origin software version 8.1 (OriginLab Corporation, Northampton, MA, USA).

\section{Results}

\subsection{Extracts of Plant Powders Show Presence of a Number of Phytochemicals}

\subsubsection{Qualitative Analysis of Secondary Metabolites}

The ethanol extract of the $R$. cordifolia powder showed the presence of alkaloids, flavonoids and terpenes while the methanol extract showed the presence of alkaloids, flavonoids, glycosides and terpenes. The aqueous extract of plant powder showed the presence of alkaloids, saponins, glycosides and terpenes. The PBS extract of powder showed the presence of alkaloids and phenols [Table 2].

Table 2. Phytochemical screening of R. cordifolia extracts in different solvents-Qualitative Assay.

\begin{tabular}{cccccc}
\hline & Assays & $\begin{array}{c}\text { Ethanol } \\
\text { Extract }\end{array}$ & $\begin{array}{c}\text { Methanol } \\
\text { Extract }\end{array}$ & $\begin{array}{c}\text { Aqueous } \\
\text { Extract }\end{array}$ & PBS \\
\hline 1 & Mayer's & - & - & - & - \\
2 & Dragendorf's & + & + & + & + \\
3 & Wagner's & - & - & - & - \\
4 & Hager's & - & - & - & - \\
5 & Saponins & - & - & + & - \\
6 & Tannins & - & - & - & - \\
7 & Phenols & - & - & - & + \\
8 & Glycosides & - & + & + & - \\
9 & Flavonoids & + & + & - & - \\
10 & Terpenes & + & + & + & - \\
11 & Steroids & - & - & - & - \\
12 & Quinones & - & - & - & - \\
13 & Carotenoids & - & - & - & - \\
\hline
\end{tabular}

\subsubsection{Quantification of Phenols and Flavonoids in Plant Extracts}

To quantify these results, first standard curves were generated for phenols (with gallic acid) and flavonoids (with quercetin). These assays were repeated both for presence and absence of PVPP. The results are depicted in Figure 1. Ethanol and methanol extracts of powders had 75\%, more phenol and flavonoid content compared to aqueous and PBS extracts for $1 \mathrm{mg} / \mathrm{mL}$ concentration of extracts [Tables 3 and 4].

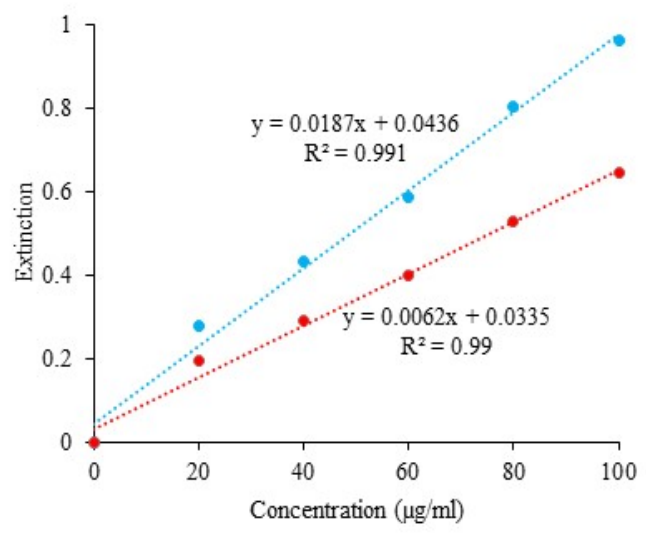

(a)

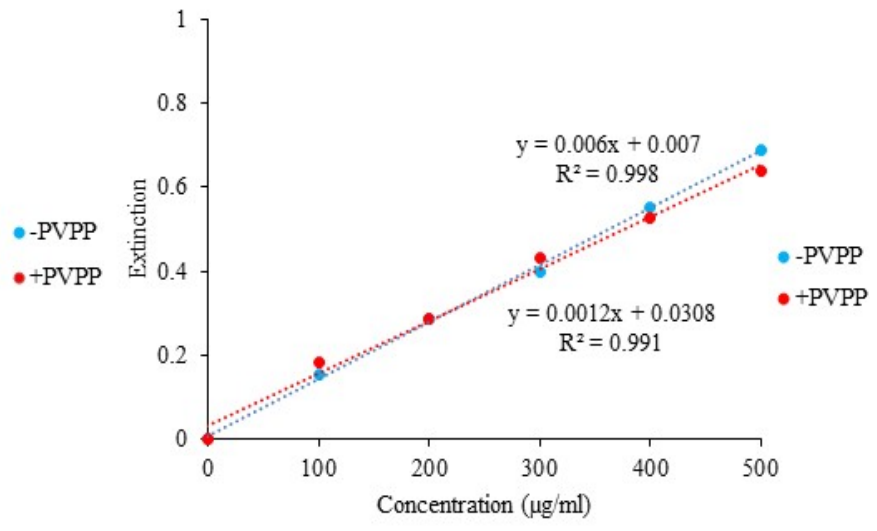

(b) 
Figure 1. (a) Standard curve of gallic acid without (blue) and with (red) PVPP for Phenols; (b) Standard curve of quercetin without (blue) and with (red) PVPP for Flavonoids.

Table 3. Quantification of phenol contents of powder extracts of R. cordifolia.

\begin{tabular}{ccccccccc}
\hline $\begin{array}{c}\text { Extracts in } \\
\text { Solvent }\end{array}$ & PVPP & \multicolumn{3}{c}{ Absorbance } & \multicolumn{5}{c}{$\begin{array}{c}\text { Gallic Acid Equivalent, } \\
\text { GAE }(\mu \mathrm{\mu g} / \mathrm{mL})\end{array}$} & $\begin{array}{c}\text { Phenol content } \\
(\mathrm{GAE}) \text { Mean Value }\end{array}$ \\
\hline Ethanol & - & 0.735 & 0.736 & 0.733 & 36.97 & 37.02 & 36.86 & $36.95 \pm 0.08^{\mathrm{a}, \mathrm{f}}$ \\
& + & 0.067 & 0.066 & 0.069 & 5.40 & 5.24 & 5.72 & $5.45 \pm 0.24$ \\
Methanol & - & 0.444 & 0.447 & 0.449 & 21.41 & 21.57 & 21.67 & $21.55 \pm 0.13^{\mathrm{a}, \mathrm{c}, \mathrm{e}}$ \\
& + & 0.07 & 0.074 & 0.079 & 5.88 & 6.53 & 7.33 & $6.58 \pm 0.72$ \\
Aqueous & - & 0.667 & 0.668 & 0.669 & 33.33 & 33.39 & 33.44 & $33.39 \pm 0.05^{\mathrm{a}, \mathrm{b}, \mathrm{d}, \mathrm{g}}$ \\
& + & 0.074 & 0.077 & 0.076 & 6.53 & 7.01 & 6.85 & $6.80 \pm 0.24$ \\
PBS & - & 0.374 & 0.371 & 0.377 & 17.66 & 17.50 & 17.82 & $17.66 \pm 0.16^{\mathrm{a}, \mathrm{b}}$ \\
& + & 0.069 & 0.079 & 0.075 & 5.72 & 7.33 & 6.69 & $6.58 \pm 0.81$ \\
\hline
\end{tabular}

Phenol content (GAE) in last column is expressed as mean \pm SEM $(n=3){ }^{a-g}$ Column wise values with different superscripts of this type indicate significant difference $(\mathrm{p}<0.001)$, a between -PVPP and + PVPP for same solvent, ${ }^{\mathrm{b}-\mathrm{g}}$ for -PVPP, $\mathrm{b}$ between Ethanol and PBS, c between Ethanol and Methanol, d between Ethanol and Aqueous, e between Aqueous and PBS, ${ }^{\mathrm{f}}$ between Aqueous and Methanol, $\mathrm{g}$ between Methanol and PBS.

Table 4. Quantification of flavonoid contents of powder extracts of $R$. cordifolia.

\begin{tabular}{|c|c|c|c|c|c|c|c|c|}
\hline \multirow{2}{*}{$\begin{array}{c}\text { Extracts in } \\
\text { solvent } \\
\text { Ethanol }\end{array}$} & \multirow{2}{*}{$\begin{array}{c}\text { PVPP } \\
-\end{array}$} & \multicolumn{3}{|c|}{ Absorbance } & \multicolumn{3}{|c|}{$\begin{array}{l}\text { Quercetin Equivalent, } \\
\mathrm{QE}(\mu \mathrm{g} / \mathrm{mL})\end{array}$} & \multirow{2}{*}{$\begin{array}{l}\begin{array}{l}\text { Flavonoid content } \\
\text { (QE) Mean Value }\end{array} \\
78.27 \pm 0.41^{\mathrm{a}, \mathrm{d}}\end{array}$} \\
\hline & & 0.474 & 0.477 & 0.479 & 77.83 & 78.33 & 78.66 & \\
\hline & + & 0.069 & 0.074 & 0.077 & 31.83 & 36 & 38.5 & $35.44 \pm 3.3$ \\
\hline \multirow[t]{2}{*}{ Methanol } & - & 0.528 & 0.525 & 0.524 & 86.83 & 86.33 & 86.16 & $86.44 \pm 0.34^{\mathrm{a}, \mathrm{f}, \mathrm{b}}$ \\
\hline & + & 0.077 & 0.081 & 0.084 & 38.5 & 41.83 & 44.33 & $41.55 \pm 2.9$ \\
\hline \multirow[t]{2}{*}{ Aqueous } & - & 0.251 & 0.261 & 0.255 & 40.66 & 42.33 & 41.33 & $41.44 \pm 0.83^{\mathrm{a}, \mathrm{g}, \mathrm{c}, \mathrm{e}}$ \\
\hline & + & 0.057 & 0.059 & 0.055 & 21.83 & 23.5 & 20.16 & $21.83 \pm 1.6$ \\
\hline \multirow[t]{2}{*}{ PBS } & - & 0.226 & 0.225 & 0.233 & 36.5 & 36.33 & 37.66 & $36.83 \pm 0.72^{\mathrm{a}, \mathrm{g}}$ \\
\hline & + & 0.06 & 0.062 & 0.069 & 24.33 & 26 & 31.83 & $27.38 \pm 3.9$ \\
\hline
\end{tabular}

Flavonoid content (QE) in last column is expressed as mean \pm SEM $(n=3)$, ${ }^{a-g}$ Column wise values with different superscripts of this type indicate significant difference $(\mathrm{p}<0.001)$, a between -PVPP and +PVPP for same solvent, b-g for -PVPP, b between Methanol and PBS, c between Methanol and Aqueous, d between Methanol and Ethanol, e between Ethanol and PBS, f between Ethanol and Aqueous, g between Aqueous and PBS.

\subsection{Plant Extracts Have Antioxidant Activity}

Ascorbic acid was used as a standard that showed a significant radical scavenging activity ( $\mathrm{p} \leq$ 0.05) [Figures 2 and 3, Table 5]. Prior to PVPP treatment, in DPPH, hydrogen peroxide and reducing power assay, ethanol extract was $0.55,0.54$ and 0.95 times \% scavenging of ascorbic acid equivalent (AAE), respectively, most potent compared to standard and other extracts. In nitric oxide and total antioxidant assay, methanol extract was $93 \%$ and $82 \%$ most significant compared to standard and other extracts. Post treatment of extracts with PVPP, aqueous extract was $84 \%, 81 \%, 82 \%$ and $84 \%$ most potent in $\mathrm{DPPH}$, hydrogen peroxide, reducing power and total antioxidant assay, respectively. In nitric oxide assay methanol extract was 0.94 times \% scavenging of (AAE) most significant compared to other extracts. 

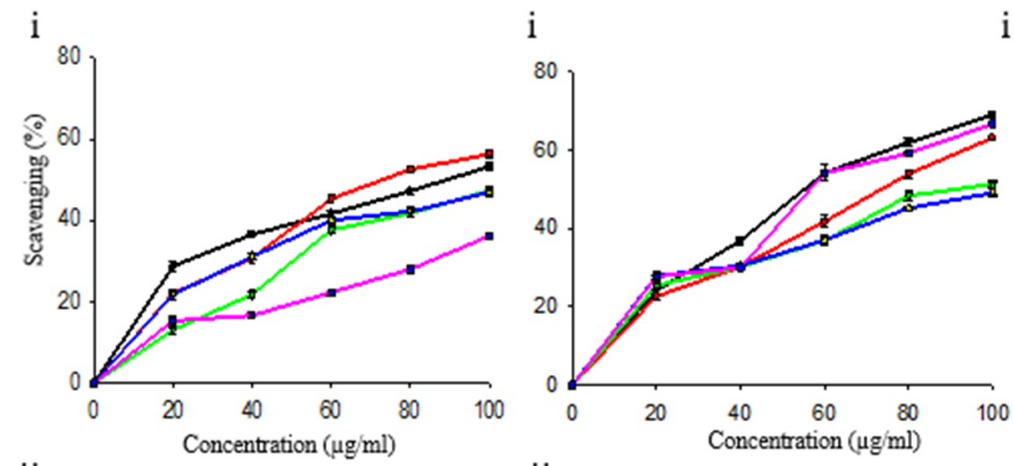

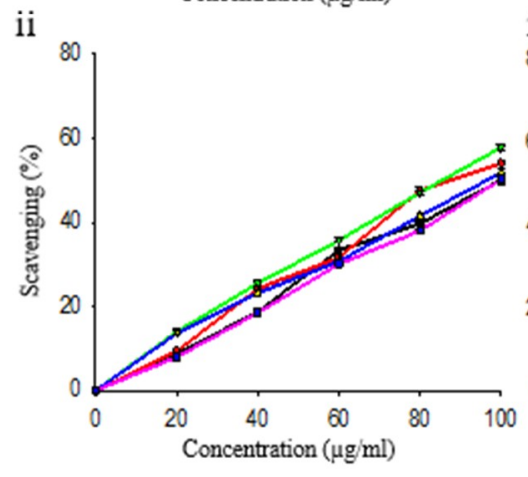

(a)

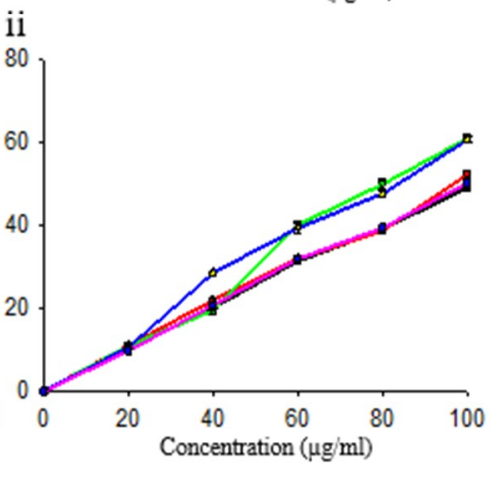

(b)
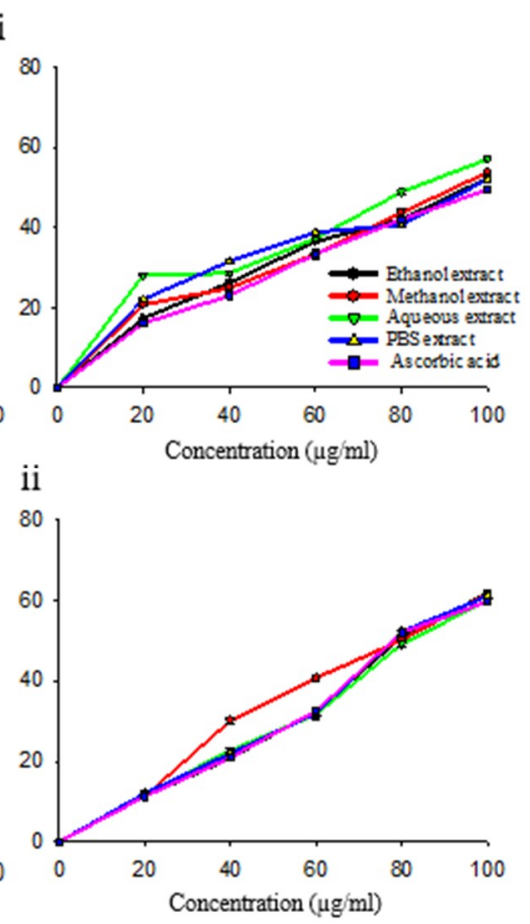

(c)

Figure 2. In vitro antioxidant assays of R. cordifolia without (i) and with (ii) PVPP for (a) DPPH assay; (b) $\mathrm{H}_{2} \mathrm{O}_{2}$ assay; (c) $\mathrm{NO}$ assay.

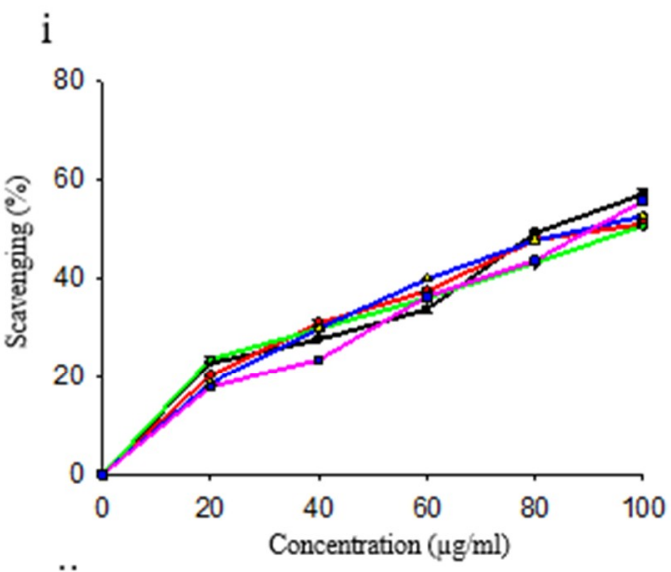

ii

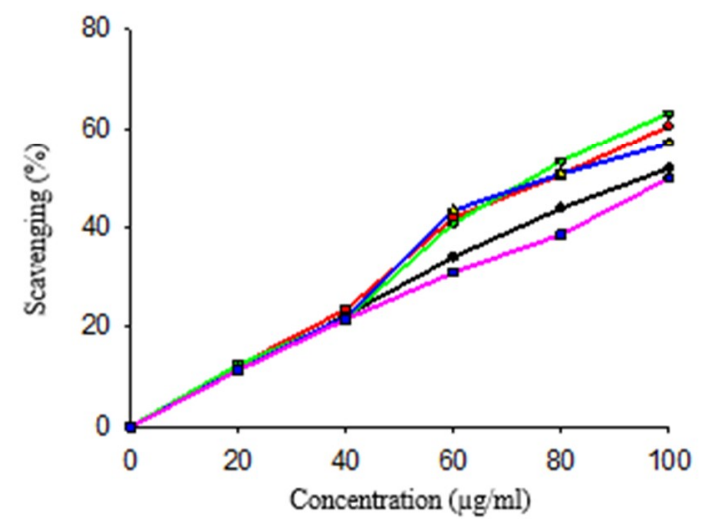

(a)

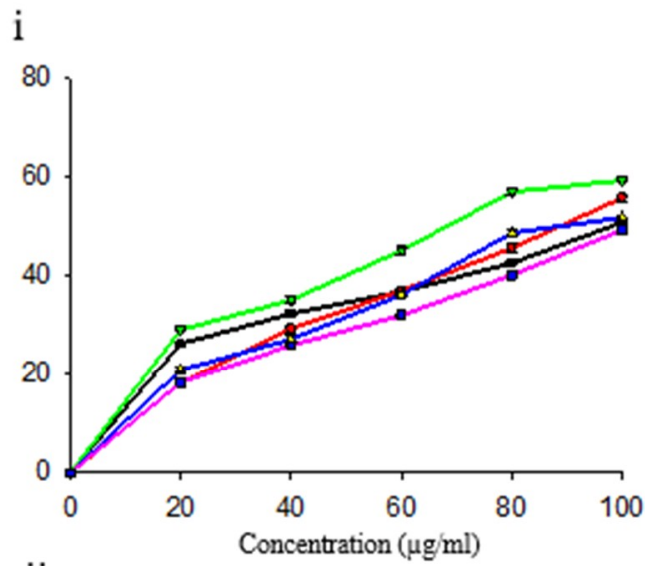

ii

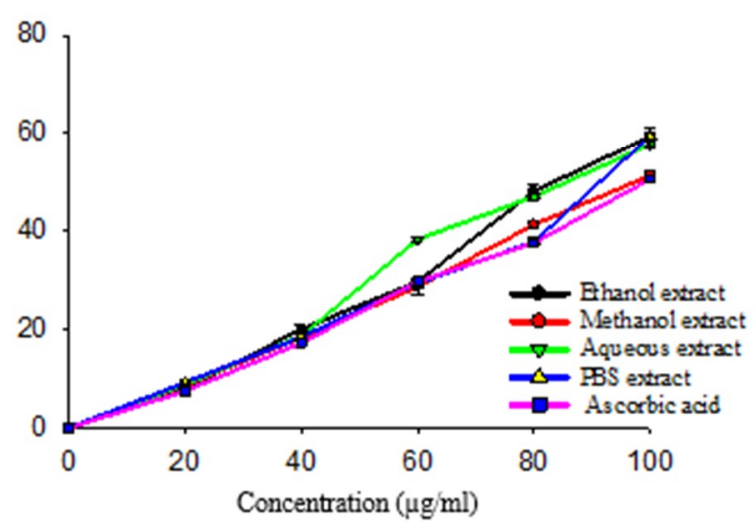

(b)

Figure 3. In vitro antioxidant assays of R. cordifolia without (i) and with (ii) PVPP for (a) Assay of reducing power; (b) Total antioxidant assay. 
Table 5. IC50 values of DPPH, Hydrogen peroxide, Nitric oxide, Reducing power and Total antioxidant assay of R. cordifolia.

\begin{tabular}{|c|c|c|c|c|c|c|c|c|c|c|}
\hline & \multicolumn{2}{|c|}{ DPPH } & \multicolumn{2}{|c|}{ Hydrogen Peroxide } & \multicolumn{2}{|c|}{ Nitric Oxide } & \multicolumn{2}{|c|}{ Reducing Power } & \multicolumn{2}{|c|}{ Total Antioxidant } \\
\hline \multirow{3}{*}{ Extracts } & IC50 & IC50 & IC50 & IC50 & IC50 & IC50 & IC50 & IC50 & IC50 & IC50 \\
\hline & $(\mu \mathrm{g} / \mathrm{mL})$ & $(\mu \mathrm{g} / \mathrm{mL})$ & $(\mu \mathrm{g} / \mathrm{mL})$ & $(\mu \mathrm{g} / \mathrm{mL})$ & $(\mu \mathrm{g} / \mathrm{mL})$ & $(\mu \mathrm{g} / \mathrm{mL})$ & $(\mu \mathrm{g} / \mathrm{mL})$ & $(\mu \mathrm{g} / \mathrm{mL})$ & $(\mu \mathrm{g} / \mathrm{mL})$ & $(\mu \mathrm{g} / \mathrm{mL})$ \\
\hline & $(-P V P P)$ & (+PVPP) & $(-P V P P)$ & $(+\mathrm{PVPP})$ & $(-P V P P)$ & $(+\mathrm{PVPP})$ & $(-P V P P)$ & (+PVPP) & (-PVPP) & $(+\mathrm{PVPP})$ \\
\hline Ethanol & 88.63 & 98.26 & 61.2 & 101.14 & 95.03 & 82.17 & 83.89 & 93.72 & 101.01 & 85.92 \\
\hline Methanol & 89.325 & 89.47 & 74.44 & 97.71 & 94.46 & 78.46 & 85.69 & 79.79 & 88.79 & 97.52 \\
\hline Aqueous & 100.256 & 85.53 & 95.42 & 80.85 & 108.21 & 84.23 & 106.36 & 77.62 & 72.39 & 85.14 \\
\hline PBS & 105.7 & 97.55 & 104.09 & 81.05 & 97.21 & 81.95 & 88.72 & 81.81 & 92.56 & 91.92 \\
\hline $\begin{array}{c}\text { Ascorbic } \\
\text { acid }\end{array}$ & 159.34 & 100.42 & 112.125 & 99.12 & 100.5 & 82.87 & 90.77 & 101.48 & 104.48 & 100.29 \\
\hline
\end{tabular}




\section{Discussion}

R. cordifolia L. produces a variety of secondary metabolites of its own metabolic activities. These metabolites are responsible for spatiotemporal sustainable and growth of the plant. Utility of secondary metabolites for human health has achieved high recognition owing to the usage in traditional/natural medication. $R$. cordifolia L. has been a less explored system and identification of suitable extract with maximal components is urgently required.

In the present study, we have selected four solvent system for extracting secondary metabolites from roots of R. cordifolia L. Quantitative analysis indicated good amount of phenols and flavonoids in the root extracts. Our method of Soxhlet extraction, led to more release of phenols and flavonoids compared to direct solubilisation of powder in respective solvents, an approach used by Desai [24] and Srabana and Kshitij [25] (ethanol, methanol and aqueous extracts). The amounts of phenols and flavonoids obtained for three extracts by these authors were 8-12 mg GAE/g of plant extract of phenols and 13-26 mg QE/g of plant extract whereas we have obtained 30-40 mg GAE/g of plant extract of phenols and 35-40 mg QE/g of plant extract.

Presence of antioxidant in the extract is crucial. Results of DPPH assay for ethanol extract reported by Zhang et al. [26] were in the range of $(23.88-65.23 \mu \mathrm{g} / \mathrm{mL})$. They used ultrasonic- assisted extraction process. These values are much lower than our results in the range of $78.25-88.63 \mu \mathrm{g} / \mathrm{mL}$. We believe suitability of extraction method is driver of differential results. Basu and Hazra [27] reported a range of $153.7-310.3 \mu \mathrm{g} / \mathrm{mL}$ for methanol and aqueous extracts as evaluated by nitric oxide assay. Here the authors used filterate of direct solubilisation of extracts in respective solvents. Our results have a better range $(94.46-108.21 \mu \mathrm{g} / \mathrm{mL})$, possibly due to our choice of method of Soxhlet exhaustive extraction process.

We are also reporting for the first time, results of R. cordifolia extracts (ethanol, methanol, aqueous and PBS) treated with PVPP for antioxidant assays. The IC50 of R. cordifolia, for DPPH assay (98.26, 89.47, 85.53 and $97.55 \mu \mathrm{g} / \mathrm{mL}), \mathrm{H}_{2} \mathrm{O}_{2}$ assay $(101.34,97.71,80.85$ and $81.05 \mu \mathrm{g} / \mathrm{mL})$, nitric oxide assay $(82.17,78.46,84.23$ and $81.95 \mu \mathrm{g} / \mathrm{mL})$, reducing power assay $(93.72,79.79,77.62$ and 81.81 $\mu \mathrm{g} / \mathrm{mL})$, total antioxidant assay $(87.92,97.52,85.14$ and $91.92 \mu \mathrm{g} / \mathrm{mL})$. Hence, even after removal of phenols and flavonoids, anti-oxidant activity is not hampered. This suggests anti-oxidant potential for different classes of secondary metabolites. High presence of antioxidant may be utilized for antiproliferative in certain cancers [1].

\section{Conclusions}

Our study has revealed presence of high anti-oxidants in root extracts of R. cordifolia. Methods of extraction is important as observed when compared reports. This work provides initial steps required in suitability of solvents for R. cordifolia extract preparations. Further work regarding anticancer potential needs to be evaluated in order to verify the extent of utility of anti-oxidant nature.

Author Contributions: S.C.K. and R.B.H. conceived and designed the experiments; R.B.H. performed the experiments; S.C.K., R.B.H., J.S. and A.A.K. analyzed the data; S.C.K. and A.A.K. contributed reagents/materials/analysis tools; S.C.K. and J.S. wrote the paper. All authors have read and agreed to the published version of the manuscript.

Acknowledgments: S.C.K. would like to acknowledge Department of Technology, Savitribai Phule Pune University, Pune, India for departmental funds. Costs to publish in open access are not funded.

Conflicts of Interest: The authors declare no conflict of interest.

\section{Abbreviations}

The following abbreviations are used in this manuscript:

\section{$\mathrm{DPPH}$}

PBS

PVPP 2,2-diphenyl-1-picrylhydrazyl

Phosphate Buffer Saline

Polyvinylpolypyrrolidone 


\section{References}

1. Verma, A.; Kumar, B.; Alam, P.; Singh, V.; Kumar Gupta, S. Rubia cordifolia-A Review on Pharmaconosy and Phytochemistry. Int. J. Pharm. Sci. Res. 2016, 7, 2720.

2. Patel, P.R.; Nagar, A.A.; Patel, R.C.; Rathod, D.K.; Patel, V.R. In vitro anticancer activity of Rubia cordifolia against HeLa and Hep-2 cells-. Int. J. Pharm. Pharm. Sci. 2011, 3, 3-5.

3. Chen, Y.; Chen, P.; Bao, B.; Shan, M.; Zhang, K.; Cheng, F.; Cao, Y.D.; Zhang, L. Anti-thrombotic and proangiogenic effects of Rubia cordifolia extract in zebrafish. J. Ethnopharmacol. 2018, 219, 152-160.

4. Joharapurkar, A.A.; Zambad, S.P.; Wanjari, M.M.; Umathe, S.N. In vivo evaluation of antioxidant activity of alcoholic extract of Rubia cordifolia Linn. and its influence on ethanol-induced immunosuppression. Indian J. Pharmacol. 2003, 35, 232-236.

5. Singh, P.; Agrawal, M.; Hishikar, R.; Joshi, U.; Maheshwari, B. Adverse drug reactions at adverse drug reaction monitoring center in Raipur: Analysis of spontaneous reports during 1 year. Indian J. Pharmacol. 2017, 49, 438-44.

6. Shilpa, P.N.; Sivaramakrishnan, V.; Devaraj, S.N. Induction of Apoptosis by Methanolic Extract of Rubia cordifolia Linn in Hep-G2 Cell Line is Mediated by Reactive Oxygen Species. Asian Pacific J. Cancer Prev. 2012, 13, 2753-2758.

7. Chang, L.C.; Chavez, D.; Gills, J.J.; Fong, H.H.S.; Pezzuto, J.M.; Kinghorn, D.A.; Rubiasins, A.-C. new anthracene derivatives from the roots and stems of Rubia cordifolia. Tetrahedron Lett. 2000, 41, 7157-7162.

8. Ghosh, S.; Sarma, M.D.; Amarendra, P.; Hazra, B. Anti-inflammatory and anticancer compounds isolated from Ventilago madraspatana Gaertn., Rubia cordifolia Linn. and Lantana camara Linn. J. Pharm. Pharmacol. 2010, 62, 1158-1166.

9. Gong, X.; Sun, Y.; Chen, W.; Guo, X.; Guan, J.; Li, D. Anti-diarrheal and anti-inflammatory activities of aqueous extract of the aerial part of Rubia cordifolia. BMC Complement. Altern. Med. 2017, 17, 1-14.

10. Yuanyuan, S.; Xuepeng, G.; Tan, J.Y.; Kang, L.; Dongyan, L.; Vikash; Yang, J.; Guang, D. In vitro antiviral activity of Rubia cordifolia aerial part extract against Rotavirus. Front. Pharmacol. 2016, 7, 1-15.

11. Adwaankar, M.K.; Chitnis, M.P. In vivo anti-Cancer activity of RC-18. Chemotherapy 1982, 28, $291-293$.

12. Patel, P.R.; Raval, B.P.; Karanth, H.A.; Patel, V.R. Potent antitumor activity of Rubia cordifolia. Int. J. Phytomedicine 2016, 2, 2008-2011.

13. Zhao, S.M.; Kuangab, B.; Fan, J.T.; Yan, H.; Xu, W.Y.; Tan, N.H. Antitumor cyclic hexapeptides from Rubia plants: History, chemistry, and mechanism (2005-2011). Chim. Int. J. Chem. 2011, 65, 952-956.

14. Bhawya, D.; Anilakumar, K.R. In Vitro Antioxidant Potency of Tinospora cordifolia (gulancha) in Sequential Extracts. Int. J. Pharm. Biol. Arch. 2010, 1, 448-456.

15. Pochapski, M.T.; Fosquiera, E.C.; Esmerino, L.A.; Brasil, E. Phytochemical screening, antioxidant, and antimicrobial activities of the crude leaves extract from Ipomoea batatas (L.) Lam. Pharmacogn. Mag. 2020, 7 , 165-170.

16. Ranatunge, I.; Adikary, S.; Dasanayake, P.; Fernando, C.D.; Soysa, P. Development of a Rapid and Simple Method to Remove Polyphenols from Plant Extracts. Int. J. Anal. Chem. 2017, 2017, 7.

17. Sulaiman, C.T.; Balachandran, I. Total phenolics and total flavonoids in selected indian medicinal plants. Indian J. Pharm. Sci. 2012, 74, 258-260.

18. Jia, Z.; Tang, M.; Wu, J. Determination of flavonoid content in mulberry and their scavenging effects on superoxide radicals. Food Chem. 1999, 64, 555-559.

19. Prabhu, K.S.; Lobo, R.; Shirwaikar, A. Free Radical Scavenging Actvity of Aqueous Extract of Sphaetanthus indicus (Linn). Pharmacologyonline 2009, 476, 468-476.

20. Ruch, R.J.; Cheng, S.J.; Klaunig, J.E. Prevention of cytotoxicity and inhibition of intercellular communication by antioxidant catechins isolated from Chinese Green Tea. Carcinogenesis 1989, 10, 10031008.

21. Pandithurai, M.; Murugesan, S. Free radical scavenging activity of methanolic extract of brown alga Spatoglossum asperum. J. Chem. Pharm. Res. 2014, 6, 128-132.

22. Prieto, P.; Pineda, M.; Aguilar, M. Spectrophotometric Quantitation of Antioxidant Capacity through the Formation of a Phosphomolybdenum Complex: Specific Application to the Determination of Vitamin E. Anal. Biochem. 1999, 269, 337-341.

23. Oyaizu, M. Studies on Products of Browning Reactions: Antioxidative Activities of Product of Browning Reaction Prepared from Glucosamine. Jpn. J. Nutr. 1986, 44, 307-315. 
24. Desai, N. Quantification of Phytochemicals in hairy root cultures of Rubia cordifolia Linn. Int. J. 2015, 3, 903913.

25. Maitra, S.; Satardekar, K. Ethano-botanical studies on Rubia cordifolia Linn. Int. J. Recent Sci. Res. 2017, 8, 22264-22267.

26. Zhang, X.; Liu, L.-J.; Song, T.-T.; Wang, Y.-Q.; Yang, X. An approach based on antioxidant fingerprintEfficacy relationship and TLC bioautography assay to quality evaluation of Rubia cordifolia from various sources. J. Nat. Med. 2014, 68, 448-54.

27. Basu, S.; Hazra, B. Evaluation of Nitric Oxide Scavenging Activity, In Vitro and Ex Vivo, of Selected Medicinal Plants Traditionally Used in Inflammatory Diseases. Phyther. Res. Int. J. Devoted Pharmacol. Toxicol. Eval. Nat. Prod. Deriv. 2006, 900, 896-900.

Publisher's Note: MDPI stays neutral with regard to jurisdictional claims in published maps and institutional affiliations.

(C) 2020 by the authors. Licensee MDPI, Basel, Switzerland. This article is an open access article distributed under the terms and conditions of the Creative Commons Attribution (CC BY) license (http://creativecommons.org/licenses/by/4.0/). 